\title{
Occupational Health: Farmers Knowledge on Pesticide usage and it's Harmful Effects on Human Health in Rural Areas of South India
}

\author{
Gulappa Devegappanavar* \\ School of Environmental Science, Public Health and Sanitation Management, Karnataka State Rural Development and \\ Panchayat Raj University, Gadag - 582101, Karnataka, India; gulappa.md07dmr@gmail.com
}

\begin{abstract}
An estimated 1.3 billion workers are engaged in agricultural production worldwide. This represents half of the total world labor force. Almost $60 \%$ of them are in developing countries. Pesticides can enter the human body by three common ways: Through the skin (contact), the mouth (ingestion) and the lungs (inhalation). The state of the chemical, i.e. solid, liquid or gas, affects the chances of pesticide penetration into the body. During the usage of pesticides farmers reported problems such as eye irritation, headache, dizziness, breathing difficulty, skin rashes and all of these symptoms at least once during their exposure to pesticides. A field based cross sectional study was conducted in the rural areas of Karnataka state, Gadag district, to assess the farmer's knowledge, attitudes and practices about pesticide usage and its harmful effects on human health. A pre-tested semi-structured questionnaire was used to obtain the data from January to February 2020. Data was collected at the rural settings by visiting their house and agriculture fields. Totally 265 farmers were interviewed, out of that more than half of them have good knowledge about pesticide usage but only few of them have knowledge about the harmful effects of pesticide on their health. In our study findings majority of the farmers are not aware about the health hazards due to usage of pesticides, they showed good attitude and poor practices about pesticide usage.
\end{abstract}

Keywords: Attitude and Practices, Farmers Knowledge, Health Awareness, Occupational Health, Occupational Hazard

\section{Introduction}

Agreat majority of agricultural workers are found in Asia, which is the most densely populated region of the world, with more than $40 \%$ of the world's agricultural population concentrated in China and more than $20 \%$ in India ${ }^{1}$. In India inadequate safety precautions by workers using or manufacturing pesticides, health checks for employees or workers, labeling of chemical products and chemical contamination of food, unsafe storage of chemicals in the home, environmental pollution from industry often due to uncontrolled disposal of waste are the major causes for occupational hazards ${ }^{2}$. Mixing and spraying are the tasks associated with the greatest intensity of pesticide exposure, given that during this phase farmers are exposed to the concentrated product and, therefore, often face high exposure events ${ }^{3,4}$. Studies on pesticide dermal contamination highlight that the spray deposition the sprayers bodies is crucial as these results indicated that all the farmers were at risk from the pesticides they used ${ }^{5}$. The working environment frequently contains a wide variety of chemical, physical, biological and psychosocial health hazards. The early detection and assessment of occupational hazards fall under the discipline of occupational hygiene ${ }^{6}$. In this study we wanted to assess the rural area farmer's knowledge about the pesticide usage and its harmful effects on human health.

\section{Materials and Methods}

\subsection{Study Design}

A field based cross sectional study was conducted in rural areas of Gadag district on farmers. Purposive sampling technique was used to recruit the study participants. Socio-demographic details, knowledge, attitudes and practices about the pesticide

*Author for correspondence 
usage and its harmful effects on farmers health related data was obtained using pre-tested semi-structured questionnaire.

\subsection{Study Setting}

A field based cross sectional study was conducted in the rural areas of Gadag district on farmers. Data was obtained from January to February 2020 using a pre-tested semi-structured interview questionnaire.

\subsection{Participants}

Those who were involved in the agriculture activity and have experience of previously used the pesticides and those who have at least once sprayed the pesticide and among them those who given oral consent to participate in the study were included.

\subsection{Variables}

Independent variables: Gender, age, education and income status.

Dependent variables: knowledge was assessed using semistructured questionnaire.

\subsection{Data Sources}

Primary data was obtained introducing the questionnaire to farmers. Visited the farmer's agriculture fields and questionnaire was administered related to pesticide usage and its harmful effects on their health.

\subsection{Study Size}

KSRDPR University was located in the Gadag district headquarters. Purposive sampling technique method was used to recruit the study participants. Totally 265 farmers data was collected from the 5 villages.

\subsection{Statistical Methods}

Data was entered into excel sheet, analyzed using SPSS v20 and expressed in frequency and percentages.

\section{Results}

In the current study majority of the participants belongs to 41-50 age group, half of them are completed primary education and all most all are married (Table 1).

In the north Karnataka majority of the farmers grown commercial crops and in Nagavi majority of farmers grown vegetables (Table 2).

In our study almost all the farmers have knowledge about definition of pesticide, its name, how many times it should be sprayed, storage and its safe usage. Majority of the farmers
Table 1. Socio-demographic details of study participants

\begin{tabular}{|l|c|c|}
\hline Characteristics & & Frequency (\%) \\
\hline \multirow{4}{*}{ Gender } & Male & $232(87.5)$ \\
\cline { 2 - 3 } & Female & $33(12.5)$ \\
\hline \multirow{5}{*}{ Age Group } & $20-30$ & $17(06.4)$ \\
\cline { 2 - 3 } & $31-40$ & $82(30.9)$ \\
\cline { 2 - 3 } & $41-50$ & $89(33.6)$ \\
\cline { 2 - 3 } & $51-60$ & $56(21.1)$ \\
\hline \multirow{5}{*}{ Education level } & 61 and above & $21(07.9)$ \\
\cline { 2 - 3 } & Illiterate & $57(21.5)$ \\
\cline { 2 - 3 } & Primary & $113(42.6)$ \\
\cline { 2 - 3 } & Secondary & $74(27.9)$ \\
\cline { 2 - 3 } & Undergraduate & $13(04.9)$ \\
\cline { 2 - 3 } & Graduate & $08(03.0)$ \\
\hline Marital status & Single & $10(03.8)$ \\
\cline { 2 - 3 } & Married & $255(96.2)$ \\
\hline
\end{tabular}

Table 2. Frequency distribution of types of crops harvesting in 5 villages

\begin{tabular}{|l|c|c|c|c|c|}
\hline \multirow{2}{*}{ Villages } & \multicolumn{5}{|c|}{ Types of crops harvest } \\
\cline { 2 - 6 } & Vegetables & $\begin{array}{c}\text { Food } \\
\text { grains }\end{array}$ & $\begin{array}{c}\text { Commercial } \\
\text { crops }\end{array}$ & Fruits & All \\
\hline Binkadakatti & 24 & 11 & 2 & 0 & 0 \\
\hline Hulkoti & 4 & 17 & 20 & 7 & 11 \\
\hline Kalasapur & 3 & 4 & 35 & 14 & 0 \\
\hline Kurthkoti & 21 & 7 & 30 & 1 & 3 \\
\hline Nagavi & 34 & 4 & 13 & 0 & 0 \\
\hline Total & 86 & 43 & 100 & 22 & 14 \\
\hline
\end{tabular}

were aware about necessity of reading the label on pesticide prior to its usage and nearly half of them know the names of banned pesticides (Table 3).

In the present study majority (36.6\%) of the study participants responded that pesticide residue will exist in air, soil, surface water and fruits, seeds, leaves of crop. For the question disposal of pesticide containing majority $(26.8 \%)$ of the responded, they will burn the containers (Table 4).

In this study all farmers replied that they were aware about the adverse health effects of pesticides and if they get exposed then they will visit the hospital. If they saw the pesticide poisoned person they will take them into the hospital, nearly half of the farmers responded that they will wash pesticide contacted skin with soap and water. None of them aware about the poison information centre and its toll free number (18004250297) (Table 5). 
Table 3. Knowledge about pesticide and its usage

\begin{tabular}{|l|c|c|}
\hline \multirow{2}{*}{ Variables } & \multicolumn{2}{|c|}{$\begin{array}{c}\text { Responses given by Farmers } \\
\text { (n - 265) }\end{array}$} \\
\cline { 2 - 3 } & Yes & No \\
\hline Do you know what is Pesticide & $257(97.0)$ & $08(03.0)$ \\
\hline $\begin{array}{l}\text { Do you know the name of the } \\
\text { pesticide which you used }\end{array}$ & $236(89.1)$ & $29(10.9)$ \\
\hline $\begin{array}{l}\text { Are you aware about how many } \\
\text { times you can sprayed the } \\
\text { pesticide }\end{array}$ & $256(96.6)$ & $09(03.4)$ \\
\hline $\begin{array}{l}\text { Do you know that pesticides } \\
\text { need to be stored separately and } \\
\text { handled safely }\end{array}$ & $251(94.7)$ & $14(05.3)$ \\
\hline $\begin{array}{l}\text { Is it Necessary to read and } \\
\text { understand the label or leaflet } \\
\text { of pesticide container prior to } \\
\text { its use }\end{array}$ & $207(78.1)$ & $58(21.9)$ \\
\hline $\begin{array}{l}\text { Do you know the names of the } \\
\text { banned pesticides }\end{array}$ & $133(50.2)$ & $132(49.8)$ \\
\hline
\end{tabular}

Table 4. Knowledge about other aspects of pesticide usage

\begin{tabular}{|l|c|c|}
\hline \multirow{2}{*}{ Variables } & \multicolumn{2}{|c|}{$\begin{array}{c}\text { Farmers responses } \\
\text { (n - 265) }\end{array}$} \\
\cline { 2 - 3 } & Frequency & Percentage \\
\hline $\begin{array}{l}\text { In which of the following pesticide } \\
\text { residues may exist }\end{array}$ & & \\
\hline Air & 33 & 12.5 \\
\hline Soil & 87 & 32.8 \\
\hline Surface water and ground water & 04 & 01.5 \\
\hline Fruits, Seeds and Leaves of crop & 28 & 10.6 \\
\hline All of the above & 97 & 36.6 \\
\hline None of the above & 04 & 01.5 \\
\hline Do not know & 12 & 04.5 \\
\hline $\begin{array}{l}\text { Which of the following ways of } \\
\text { disposal of pesticide containers or } \\
\text { bottles was safe }\end{array}$ & & \\
\hline Throw the container in garbage & 85 & 32.1 \\
\hline $\begin{array}{l}\text { Throw the container in barren land } \\
\text { or any water source }\end{array}$ & 04 & 01.5 \\
\hline Burn the container & 71 & 26.8 \\
\hline $\begin{array}{l}\text { Clean the container and use them } \\
\text { for the daily routine }\end{array}$ & 65 & 24.5 \\
\hline All of the above & 05 & 01.9 \\
\hline None of the above & & 02.3 \\
\hline Do not know & & \\
\hline
\end{tabular}

Table 5. Farmer's responses about the harmful effects of pesticide usage

\begin{tabular}{|c|c|c|}
\hline Variables & $\begin{array}{l}\text { Correct resp } \\
\text { farmers }\end{array}$ & $\begin{array}{l}\text { nse given by } \\
\text { n - 265) }\end{array}$ \\
\hline 1. Do you aware that exposure to the & Yes & No \\
\hline pesticides have adverse health effects & $256(96.6)$ & $09(03.4)$ \\
\hline $\begin{array}{l}\text { 2. Do you know that if you are } \\
\text { exposed to pesticides, you should } \\
\text { visit the hospital }\end{array}$ & $241(90.9)$ & $24(09.1)$ \\
\hline $\begin{array}{l}\text { 3. What would you do when you see } \\
\text { a person poisoned with pesticide }\end{array}$ & Frequency & Percentage \\
\hline $\begin{array}{l}\text { Find out which way the person was } \\
\text { poisoned }\end{array}$ & 05 & 01.9 \\
\hline Render the first-aid & 26 & 09.8 \\
\hline Take the person to the hospital & 194 & 73.2 \\
\hline All of the above & 36 & 13.6 \\
\hline None of the above & 04 & 01.5 \\
\hline $\begin{array}{l}\text { 4. What would you do if your skin } \\
\text { come in contact with pesticide }\end{array}$ & & \\
\hline $\begin{array}{l}\text { Wipe it off the exposed area with } \\
\text { clothes }\end{array}$ & 08 & 03.0 \\
\hline $\begin{array}{l}\text { Wash the exposed area with soap } \\
\text { and water }\end{array}$ & 147 & 55.5 \\
\hline $\begin{array}{l}\text { Make a call to the poison } \\
\text { information centre }\end{array}$ & 00 & 00 \\
\hline Go to the nearest hospital & 108 & 40.0 \\
\hline Do not do anything & 02 & 00.8 \\
\hline $\begin{array}{l}\text { 5. What would you do in case of } \\
\text { accidental spillage of pesticides into } \\
\text { your eyes }\end{array}$ & & \\
\hline Wash the eyes with water & 123 & 46.4 \\
\hline $\begin{array}{l}\text { Make a call to the poison } \\
\text { information centre }\end{array}$ & 00 & 00 \\
\hline $\begin{array}{l}\text { Take the person to the nearest } \\
\text { hospital }\end{array}$ & 140 & 52.8 \\
\hline Do not do anything & 02 & 00.8 \\
\hline
\end{tabular}

In our findings majority of the farmers opined that pesticide can enter all routes (Nose, mouth, skin and eyes) and skin irritation and irregular heartbeat are the symptoms and signs (Table 6).

\section{Discussion}

\subsection{Socio-demographic Characteristics}

Majority of the farmers are males, belongs in the age group 41-50 years completed their primary education and married. 
Table 6. Farmer's responses about toxic symptoms and signs

\begin{tabular}{|c|c|c|c|}
\hline \multicolumn{2}{|l|}{ Variables } & Frequency & Percentage \\
\hline \multirow{6}{*}{$\begin{array}{l}\text { In which route } \\
\text { pesticides can } \\
\text { entry into } \\
\text { human body }\end{array}$} & Nose & 50 & 18.9 \\
\hline & Skin & 16 & 6.0 \\
\hline & Mouth & 36 & 13.6 \\
\hline & Eyes & 09 & 3.4 \\
\hline & All routes & 121 & 45.7 \\
\hline & Don’t know & 33 & 12.4 \\
\hline \multirow{11}{*}{$\begin{array}{l}\text { Which of the } \\
\text { following are } \\
\text { toxic symptoms } \\
\text { of pesticide }\end{array}$} & Headache & 67 & 25.3 \\
\hline & Watery/sore eyes & 23 & 08.7 \\
\hline & Nausea & 19 & 07.2 \\
\hline & Excessive Sweating & 01 & 00.4 \\
\hline & Cough and cold & 10 & 03.8 \\
\hline & Skin irritation & 49 & 18.5 \\
\hline & Abdominal pain & 05 & 01.9 \\
\hline & Body pain & 01 & 00.4 \\
\hline & All of the above & 47 & 17.8 \\
\hline & None of the above & 05 & 01.9 \\
\hline & Don't know & 38 & 14.3 \\
\hline \multirow{12}{*}{$\begin{array}{l}\text { When you are } \\
\text { using pesticides } \\
\text { have you } \\
\text { experienced the } \\
\text { following signs }\end{array}$} & Dizziness & 26 & 09.8 \\
\hline & Blurred vision & 15 & 05.7 \\
\hline & $\begin{array}{l}\text { Excessive } \\
\text { salivation }\end{array}$ & 20 & 07.5 \\
\hline & Hand tremor & 13 & 04.9 \\
\hline & $\begin{array}{l}\text { Convulsion } \\
\text { staggering }\end{array}$ & 17 & 06.4 \\
\hline & Narrow pupils & 11 & 04.2 \\
\hline & Vomiting & 25 & 09.4 \\
\hline & Insomnia & 21 & 07.9 \\
\hline & Breathlessness & 26 & 09.8 \\
\hline & Skin rashes & 30 & 11.3 \\
\hline & Irregular heartbeat & 34 & 12.8 \\
\hline & Diarrhea & 27 & 10.2 \\
\hline
\end{tabular}

The similar socio-demographic characteristics found in study conducted at Puducherry ${ }^{7}$.

\subsection{Types of Crops Grown}

In this area majority of the farmers grown commercial crops followed by vegetables. Similar findings found in study conducted at Karnataka ${ }^{8}$ Bangladesh $^{9}$ and Palestine ${ }^{10}$.

\subsection{Knowledge Pesticide Usage}

In our study majority of the farmers knows about where to store the pesticide containers or bottles, a study conducted at Chikkabalapur district South Karnataka found the similar findings ${ }^{11}$, Ethiopia ${ }^{12}$ and Pakistan ${ }^{13}$.

$1 / 3^{\text {rd }}$ of the farmers responded that the necessity of the reading the label on pesticide container, the similar opinion found in study conducted at Bangladesh ${ }^{9}$ and Brazil ${ }^{14}$.

In the current study almost all (96.6\%) farmers are knows that how many times they have sprayed the pesticide. A study conducted at Nigeria ${ }^{15}$ and Indonesia ${ }^{16}$ found the similar opinion.

\subsection{Knowledge on Pesticide and Containers Disposal}

We came out in the interesting findings that pesticide residue will exists in the air, soil, surface and ground water and in crops. Similar findings found in Kuwait ${ }^{17}$, Spain ${ }^{18}$ and Sweden ${ }^{19}$.

In our study majority $(32.1 \%)$ of the farmers replied that they will throw the pesticide containers in garbage followed by burned the container. A study conducted at Tanzania ${ }^{20}$ found the similar results.

\subsection{Knowledge on Harmful Effects of Pesticides on Health}

In our study majority of the farmers responded that they were aware about the adverse health effects of pesticide usage. The interesting findings found in rural village of Chikabalapur district South Karnataka ${ }^{11}$, United State of America ${ }^{4}$ and in Northern Iran ${ }^{21}$.

Farmers opined that when they saw the pesticide poisoned person they will render the first-aid and take him to the hospital, the similar advice found in World health Organization report ${ }^{2}$.

Nearly half of the famers replied that they will wash their eyes with water when they met an accidental spillage of pesticide into eyes. The review study conducted by department of agriculture development along with Democritus University of Thrace at Greece found the similar findings ${ }^{22}$.

\subsection{Knowledge on Symptoms and Signs Toxic Effect of Pesticide}

In the current study nearly half (45.7\%) of the farmers replied that pesticide will enter into the body through nose, skin, mouth and eyes. The similar study conducted in Sweden showed that pesticide will enter into body through $\operatorname{skin}^{19}$. Similar results found in studies conducted at Palestine ${ }^{10}$ and in Uganda ${ }^{23}$.

Among the 265 farmers majority of them replied as skin irritation and irregular heartbeat are symptoms and signs of the pesticide harmful effects on health. The similar findings found in Kuwait ${ }^{17}$.

In our findings $25.3 \%$ of the farmers opined that headache was a common symptom of pesticide usage. Similar results found in Uganda ${ }^{23}$ and in Indonesia study ${ }^{24}$. 


\section{Conclusion}

In our study majority of the farmers aware about the pesticide usage but only few of them are aware about harmful effects of the pesticide usage on health. Henceforth continuous education provision on proper mixing or spraying would increase their knowledge and helps to avoid the harmful consequence on health.

\section{Acknowledgement}

I would like to acknowledge the Master of Public Health Scholars of Karnataka State Rural Development and Panchayat Raj University, Gadag for helping the data collection and Vice Chancellor (Acting) and Registrar of our university Prof. Dr. S. V. Nadagoudar and Honorary Professor Dr. Suresh Kishan Rao for their support to conduct this research.

\section{References}

1. International Labor Office. Safety and Health in Agriculture. p. 1-24.

2. WHO. Guidelines on the prevention of toxic exposures Education and public awareness activities [Internet]. International Programme on Chemical Safety. 2004. http://www. who.int/ipcs/features/prevention_guidelines.pdf

3. Damalas CA, Koutroubas SD. Farmers' exposure to pesticides: Toxicity types and ways of prevention. Toxics. 2016; 4(1):1-10. PMid: 29051407 PMCid: PMC5606636. https://doi.org/10.3390/ toxics 4010001

4. Lichtenberg E, Zimmermanu R. Adverse Health Experiences, Environmental Attitudes and Pesticide usage Behavior of Farm Operators. 1999; 19(2):283-94. PMid: 10765405. https://doi. org/10.1111/j.1539-6924.1999.tb00405.x

5. Tamrin PDSBHM. Occupational safety and health in commodity agriculture: Case studies from Malaysian agricultural perspective. 2015. p. 1-433.

6. Gittleman J. Early detection of occupational diseases. Ind Labor Relations Rev. 1988; 42(1):126. https://doi. org/10.1177/001979398804200113

7. Mohanty MK, Behera BK, Jena SK, Srikanth S, Mogane C, Samal $\mathrm{S}$, et al. Knowledge attitude and practice of pesticide use among agricultural workers in Puducherry, South India. Journal of Forensic and Legal Medicine. 2013; 20:1028-31. PMid: 24237813. https://doi.org/10.1016/j.jflm.2013.09.030

8. Shetty PK, Murugan M, Hiremath MB, Sreeja KG. Farmers' education and perception on pesticide use and crop economies in Indian agriculture. J Exp Sci. 2010; 1(October 2014):3-8.

9. Shammi M, Sultana A, Hasan N, Mostafizur Rahman M, Saiful Islam M, Bodrud-Doza $\mathrm{M}$, et al. Pesticide exposures towards health and environmental hazard in Bangladesh: A case study on farmers' perception. J Saudi Soc Agric Sci [Internet]. 2020; 19(2):161-73. Available from: https://doi.org/10.1016/j. jssas.2018.08.005
10. Yassin MM, Abu Mourad TA, Safi JM. Knowledge, attitude, practice and toxicity symptoms associated with pesticide use among farm workers in the Gaza Strip. Occup Environ Med. 2002; 59(6):387-93. PMid: 12040114 PMCid: PMC1740291. https://doi.org/10.1136/oem.59.6.387

11. Satya Sai MV, Devi Revati G, Ramya R, Swaroop AM, Eswaran Maheswari MMK. Knowledge and perception of farmers regarding pesticide usage in a rural farming Village, Southern India. Indian J Occup Environ Med. 2019; 23(1):32-6.

12. Negatu B,KromhoutH,Mekonnen Y,Vermeulen R. Useofchemical pesticides in Ethiopia: A cross-sectional comparative study on knowledge, attitude and practice of farmers and farm workers in three farming systems. Ann Occup Hyg. 2016; 60(5):551-66. PMid: 26847604. https://doi.org/10.1093/annhyg/mew004

13. Mubushar M, Aldosari FO, Baig MB, Alotaibi BM, Khan AQ. Assessment of farmers on their knowledge regarding pesticide usage and biosafety. Saudi J Biol Sci [Internet]. 2019; 26(7):1903-10. PMid: 31762673 PMCid: PMC6864180. https:// doi.org/10.1016/j.sjbs.2019.03.001

14. Pasiani JO, Torres P, Silva JR, Diniz BZ, Caldas ED. Knowledge, attitudes, practices and biomonitoring of farmers and residents exposed to pesticides in Brazil. Int J Environ Res Public Health. 2012; 9(9):3051-68. PMid: 23202670 PMCid: PMC3499853. https://doi.org/10.3390/ijerph9093051

15. Irenonsen UO, Igbokwe EM, Enwelu IA. Knowledge and practices of herbicide use among farmers in Edo State, Nigeria. Int J Soc Relev Concern. 2015; 3(4):1-8.

16. Relationship of pesticide spraying to signs and symptoms in Indonesian farmers.

17. Jallow MFA, Awadh DG, Albaho MS, Devi VY, Thomas BM. Pesticide knowledge and safety practices among farm workers in Kuwait: Results of a survey. Int J Environ Res Public Health. 2017; 14(4):340. PMid: 28338612 PMCid: PMC5409541. https://doi.org/10.3390/ijerph14040340

18. Lo E, Martı E, Arias-este M, Mejuto J, Garc1 L. The mobility and degradation of pesticides in soils and the pollution of groundwater resources. 2007.

19. Blanco LE, Aragon A, Lundberg I, Liden C, Wesseling C, Nise G. Determinants of dermal exposure among Nicaraguan subsistence farmers during pesticide applications with backpack sprayers. Ann Occup Hyg. 2005; 49(1):17-24.

20. Lekei EE, Ngowi AV, London L. Farmers' knowledge, practices and injuries associated with pesticide exposure in rural farming villages in Tanzania. BMC Public Health. 2014; 14(1):1-13. PMid: 24754959 PMCid: PMC3999359. https://doi.org/10.1186/14712458-14-389

21. Taghdisi MH, Besheli BA, Dehdari T, Khalili F. Knowledge and practices of safe use of pesticides among a group of farmers in Northern Iran. Int J Occup Environ Med. 2019; 10(2):66-72. PMid: 31041923 PMCid: PMC6524735. https://doi.org/10.15171/ ijoem.2019.1479

22. Damalas CA, Eleftherohorinos IG. Pesticide exposure, safety issues and risk assessment indicators. Int $\mathrm{J}$ Environ Res Public Health. 2011; 8(5):1402-19. PMid: 21655127 PMCid: PMC3108117. https://doi.org/10.3390/ijerph8051402 
23. Oesterlund AH, Thomsen JF, Sekimpi DK, Maziina J, Racheal A, Jørs E. Pesticide knowledge, practice and attitude and how it affects the health of small-scale farmers in Uganda: A crosssectional study. Afr Health Sci. 2014; 14(2):420-33. PMid: 25320593 PMCid: PMC4196420. https://doi.org/10.4314/ahs. v14i2.19
24. Yuantari MGC, Van Gestel CAM, Van Straalen NM, Widianarko B, Sunoko HR, Shobib MN. Knowledge, attitude and practice of Indonesian farmers regarding the use of personal protective equipment against pesticide exposure. Environ Monit Assess. 2015; 187(3). PMid: 25716528. https://doi.org/10.1007/s10661015-4371-3. 